\title{
Landscape architecture as an entity of property development in Wilayah Persekutuan, Putrajaya
}

\author{
Ahmad Nasyution bin Abdul Razak ${ }^{1 *}$ and Anuar bin Alias ${ }^{2}$ \\ ${ }^{1}$ Department of Estate Management, Faculty of Built Environment, University of Malaya, 50603 Kuala Lumpur, \\ Malaysia \\ ${ }^{2}$ Centre for Construction, Building and Urban Studies (CeBUS), Faculty of Built Environment, University of \\ Malaya, 50603 Kuala Lumpur, Malaysia \\ *supermahkota@gmail.com
}

\begin{abstract}
This study explores the relationship between landscape architecture and property development. Landscape architecture emphasizes the nature of conservation, development of public parks, city parks, local parks, artificial forests, lakes, recreational areas, outdoor recreation centers, open space systems and other components of landscape architecture in providing opportunities and benefits for real estate development. Backed by ample literature review, this study reveals the significant relationship between land, real estate and landscape architecture. Landscape architecture which provides an open park and green space can be expanded to benefit the social, environment and economy through optimal used of space in property development project. Hence, this study discusses the objectives which are to determine significant factors in the development of landscape architecture, to identify the importance of landscape architecture in real estate development, and to assess the relationship between landscape architecture and property development land. This study involved 50 respondents from renowned developers; Putrajaya Holdings Sdn Bhd (PJH), Selangor State Development Corporation (PKNS), the local authority; Putrajaya Corporation (PPJ), Kajang Municipal Council (MPKj), relevant agencies; Valuation and Property Services Department-JPPH (Ministry of Finance), Department of Town and Country Planning (Peninsular Malaysia), developers registered with ReHDA and residents / property owners in the study area. To conclude, this study offers adequate benefits to policy makers, also relevant agencies such as the local authorities, landowners, property developers, the relevant professionals and communities on the positive effects and significant relationships between landscape architecture and property development.
\end{abstract}

Keywords: landscape architecture, real estate, property development, relationship, assess

\section{INTRODUCTION}

Property development is an important component of the economy. Thus, it is necessary to have a clear and transparent policy used for property development as a major contribution to the economy of the country. The property is an affordable and transferable asset, so the effectiveness of economic regulation that guides other commodities will also guide the properties (Mani, 2006). Real estate as a commodity requires the price mechanism to produce accurate and balanced valuation methods so that the mechanism can be effective and efficient.

The property market may not be completely perfect. This vulnerability requires specialization and expertise to be able to interpret and determine the market value of that assessment despite the imperfection, but the traded assets can be allocated and interpreted accurately. The property market has consistently shown that people are willing to pay more for properties located in areas with quality landscape, normally close to parks and open space. These areas will get the benefit of appreciation in capital value. The high value for this property means that the owners pay higher property taxes. In fact, this is the capitalization of land use on park property. In most relationships where the parks increase the property value, property tax increases will be placed into the general fund along with all other property tax collections.

\section{LAND AND REAL ESTATE}

The economic development of a country in particular, or the country in general, is the development that the real estate industry will account for in a single industry.

\subsection{LAND}

National Land Code 1965, Act 56 of 1965 provides for the definition of land under Section 5 of the land and this includes: 
a) The face of the earth and all things that make the earth such as rocks and sand.

b) The soil under the surface of the earth and all things therein as mineral rocks.

c) All plants and other natural products such as trees.

d) All of the things attached to the earth either above or below the earth's surface.

e) Lands covered by water such as water rights.

In a Latin term, the property definition is ad caelo usque ad centrum which means from the air to the center of the earth. This could indicate that, in theory, the land is one that is anything on the surface of the earth, the earth itself and anything beneath it to the earth.

\subsubsection{Real Estate}

According to Osman (2006), the property consists of lands, buildings and resources on them. It includes residential homes or buildings erected on the land. It also represents vacant lands or open areas, whether used for parking, green spaces for city beautification, planting grass or land for industrial development.

The property is unique in that it has a special attribute that is different from other commodities.

Among them are:

a) The property is heterogeneous in nature.

b) The property is durable. Land or site is permanently barring erosion, holding or transferring human activities such as road constructions.

c) Real estate can serve a wide range of interests such as permanent interest, tax etc.

d) Usually the market price or value of the property capital is higher when compared to other commodities.

e) Legislation governing property is primarily related to the possession and ownership of planning and development.

f) Supply of the property is limited. This means we cannot add the quantity of land unless the number of floors of a building is altered or added after obtaining the planning approval.

g) The demand for property is generally high compared to its offer because of the need for land and houses.

h) Investment property generally involves the property purchased for investment purposes e.g. for rental, or for capital appreciation through higher resale price.

i) Property involving high management costs such as tax assessment and land, building repair costs, the costs of collection and transfer of rent, fire insurance and management costs of the building itself. Among the key elements of the property is the commodity market, and the property market is a market that is unique and different, when compared to market goods or other commodities.

\subsection{RELATIONSHIP OF LAND AND REAL ESTATES}

\subsubsection{The Types of Land in Malaysia}

National Land Code 1965, specifies two separate concepts of classification and category. According to the classification of the land, it can be divided into two classes:

a) land on the coastline of the land can be disposed of by the State by means of the acquisition of ownership or other types of alienation.

b) the edge of the beach and the sea and the seacoast cannot be disposed of in any way whatsoever.

By category, there are four categories of land use- agricultural, commercial, residential and industrial land use.

Classification also contains several provisions relating to the nature of soils, the State Land (State Land), Malay Land Reserve and Alienated Land. The Mining Land is also located under the Mining Enactment 1935 and the Federated Malay reserve land is under Reserve Land Enactment/ Malay reserve of the Federated Malay States in 1935.

\subsection{CHARACTERISTICS OF REAL ESTATE}

Properties are compared with other commodities in terms of their management, values, interests, pricing the property until the property purchase process. Everything is carried out in an orderly and confidential manner. This makes the property a commodity as well as an exclusive source of investment. The property also has its own characteristics that fall into its physical state, its institutions, its economy and its markets.

\subsection{LAND, REAL ESTATE AND LANDSCAPE ARCHITECTURE}

Land is a basic world commodity. According to Laurie (1975), the land becomes a landscape when it is described or viewed in terms of the earth and environmental features (physiographic and environmental characteristics). The diversity of landscapes based on these features is based on the history of human impact upon the landscape, and is further a reflection of this dynamic, naturalness and social system. 
Landscape architecture emphasises on the planning and design of land and water for use by the local community as well as on the understanding of the system. Planning acts as a futuristic approach, where the land is regarded as a source of judgment in relation to the demands and expectations of the society's needs and values. Design refers to the use of qualitative or functional layout of the land contained in the planning process for social -specific functions such as housing, education or recreation.

According to the Institute of Landscape Architects Malaysia (1995), landscape architecture is the art and science of design, planning or management of land, natural and man-made structures and objects, when the soil is utilised through the application of scientific knowledge and culture in the study of ecology and behavior, with concern for natural resource conservation and stewardship of the land and which enables improvement in the quality of outdoor space for human use and appreciation.

In the theory of landscape architecture, Laurie (1975), states that there are five main components of the theory: natural processes, social processes, methodology, technology and value. Whatever the scale or the emphasis of the operation, all components are consistently relevant to one another.

\subsubsection{Physical entities}

The development of landscape architecture as municipal parks, recreational areas and theme parks should be seen as a physical entity that developing land with other improvements (Mar Iman, 2005). Land which contains the development of landscape architecture may consider aspects such as size, shape, content creation, topsoil (epipedon), subsoil (endopedon), accessibility and so on. Repair formed from the development of a managed landscape architecture can be seen as a building, open space and recreation, natural or artificial elements of water, plants and so on.

The development of landscape architecture is also seen in terms of the points relative to the landscape, such as the placement of the center, commercial center, the city and other seemingly accessible properties.

\subsubsection{Economic entity}

Involved the activities of planning, investment, development, maintenance and so on.

\subsubsection{Social and Institutional Entities}

Involving the local communities and related laws and regulations, culture and other development activities.

\subsection{NATIONAL LANDSCAPE POLICY}

According to the Ministry of Housing and Local Government (2010), the Landscape Policy was formulated as a comprehensive operational guide based on the significance of the local natural landscape and environmental sustainability. The policy was approved by the Cabinet on $22^{\text {nd }}$ December 2010, to be used as a reference and operational guidelines for developing and maintaining the landscape as a national treasure under the following settings:

a) Vision:

Malaysia's most beautiful national parks in year 2020.

b) Policy Statement:

Creating a sustainable landscape work and nature-based national vision Malaysia in beautiful parks.

\subsubsection{Principles of the National Landscape Policy}

To strengthen the National Landscape Policy, a number of principles to achieve the policy are outlined as follows:

i. Conservation ethics natural landscape that is deeply rooted in the religious and cultural values of all Malaysians should be maintained.

ii. Sources of natural landscape is a treasure that should be preserved and sustainably managed as an investment to benefit the country.

iii. The natural landscape, climate and local ecology will produce quality living environment.

iv. The landscaping of the country through the concerted efforts at the national, state and local levels and through laws at these levels is the responsibility of all levels of the society.

v. The government is responsible for implementing the National Landscape Policy in close cooperation of all parties.

vi. Public awareness and education are essential to achieve the objective of making Malaysia as a country with beautiful parks.

\subsubsection{Core of National Landscape Policy}

The creation of the National Landscape Policy is based on some core policies: 
i. To inculcate a love of landscape.

ii. To strengthen and improve the quality of the landscape in order to achieve the most beautiful national parks.

iii. To develop a program for infrastructure development landscape for the provision of functional and sustainable green infrastructure.

iv. To protect the natural landscape as a national treasure.

v. To develop a competent organization and human resources for the development of the landscape

vi. To provide legal, regulatory and enforcement landscape.

vii. To drive the industrial landscape. (Ministry of Housing and Local Government, 2010).

\subsection{RESEARCH METHODOLOGY}

\subsection{METHODOLOGY AND DATA COLLECTION PROCEDURES}

The main method used for this research is the qualitative method through case study approach. For the purpose of data collection, primary and secondary data collection methods have been used.

\subsection{LEVEL DATA COLLECTION}

In this study two categories of data have been collected as follows:

i. Primary Data

For this study, primary data are collected through a questionnaire survey and oral interviews with the related parties.

\section{ii. Secondary Data}

Secondary data are data that are created for individuals or institutions that typically seek to strengthen the primary data. Secondary data involved in this study include those from reference books, journal reports, articles and other resources.

The process of primary data collection was done using two methods, namely through the distribution of questionnaires and interviews disseminated to registered developers involved with the Association of Real Estate and Housing Developers' Malaysia (ReHDA), the owners of the Property, Valuation and Property Services Department (Ministry of Finance), Putrajaya Corporation (PPJ), Putrajaya Holdings Sdn Bhd (PJH), Kajang Municipal Council (MPKj), Selangor State Development Corporation (PKNS), the Department of Town and Country Planning
(Peninsular Malaysia) and the individuals or organizations concerned.

\subsubsection{Data Collection through Interviews}

The purpose of these interviews is to obtain specific information required, as well as to gather the views and opinion of the interviewees.

\subsubsection{Data Collection through Questionnaire}

Prior to the data collection, firstly the questionnaire is provided.

\section{RESEARCH AREA}

Putrajaya was formerly known as Prang Besar located in the area of Langat Basin. The development in the Langat Basin (Lembangan Langat) reflects the trend of urbanization as can be seen in the state and throughout the country.

\section{DATA ANALYSIS AND DISCUSSION}

\subsection{DESCRIPTIVE ANALYSIS OF THE EVIDENCE PROFILE}

The descriptive analysis of the test results shows that $62 \%$ of respondents were male, while $38 \%$ of respondents were female. In terms of marital status, $94 \%$ of respondents were married. In terms of age of the respondents, $42 \%$ are between $31-40$ years; $32 \%$ aged between $41-50$ years; $18 \%$ are 51-60 years and $8 \%$ between $21-30$ years old. On education background, $64 \%$ hold a bachelor's degree, $20 \%$ and $10 \%$ are a holder of diploma and master degree respectively. While, $4 \%$ and $2 \%$ are $\mathrm{PhD}$ and certificate holders respectively. About $36 \%$ of respondents have 3-4 children, followed by $30 \%$ with 2 children, $14 \%$ have 1 child, $10 \%$ have $5-6$ children and $10 \%$ have no children.

If viewed in terms of employment, $56 \%$ of respondents are working in the government sector, $32 \%$ are working in the professional sector and $12 \%$ in the administration. The results have shown that $60 \%$ of respondents own their houses, $18 \%$ renting, $10 \%$ stayed with their family and $2 \%$ stayed with their partner. A significant number of respondents which is $88 \%$ are Malays, Chinese $6 \%$ and $4 \%$ Indian. The majority of respondents $(62 \%)$ live in a terrace house, $22 \%$ apartment flat, $24 \%$ and $2 \%$ in bungalows and squatters, respectively. Approximately $34 \%$ of respondents have lived at this address for 4-6 years, $26 \%$ for 2-3 years, $18 \%$ have lived for over 10 years, $16 \%$ less than 1 year and $6 \%$ for $7-10$ years. 


\subsection{RELIABILITY ANALYSIS}

An analysis was conducted to test the reliability of questionnaires. The sample of 30 respondents had their answers cited for the reliability test questionnaire. Reliable instrument is one of the important factors which can obtain reliable data.
According to Nunally (1978), the Cronbach Alpha of more than 0.7 is said to be sufficient and it is an indicator of the reliability of the questionnaires. Based on the Table 1, the Cronbach Alpha ranges from 0.789 to 0.842 . These values are sufficient to validate the fact that the questionnaire is reliable.

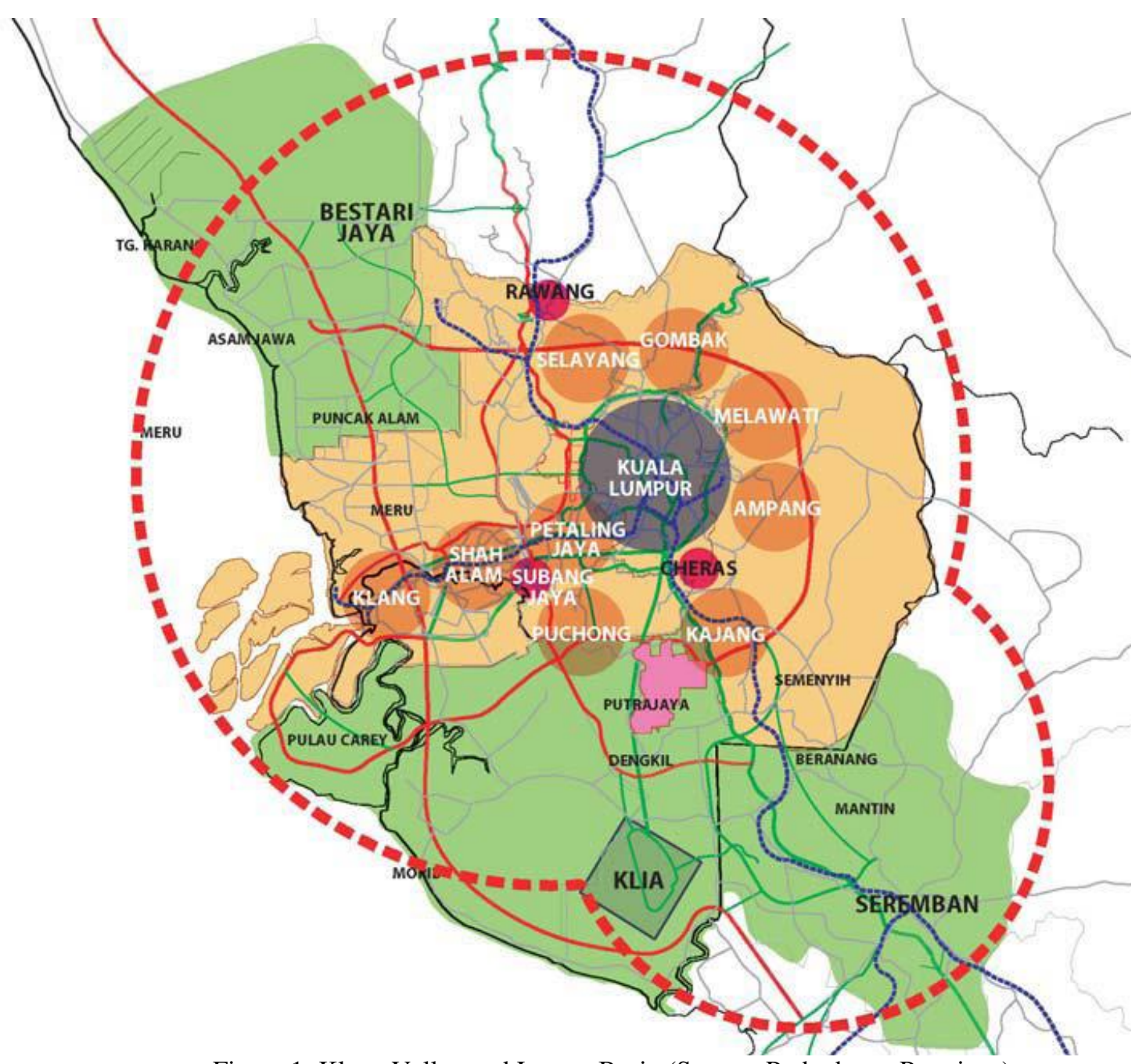

Figure 1: Klang Valley and Langat Basin (Source: Perbadanan Putrajaya)

Table 1: Results of reliability analysis

\begin{tabular}{llll}
\hline No. & Dimension & Cronbach alpha & $\mathrm{n}$ \\
\hline 1 & Relationship between landscape architecture and real estate & .829 & 11 \\
2 & Development of public space/public amenities & .834 & 9 \\
3 & The usage of urban parks & .842 & 5 \\
4 & Perception & .729 & 6 \\
5 & Satisfaction & .701 & 4 \\
6 & Health & .816 & 4 \\
7 & Urban Ecology & .799 & 6 \\
8 & Planning and Park design & .789 & 6 \\
\hline
\end{tabular}


Table 2: Feedback of the respondents on the relationship between landscape architecture and property

\section{No. Statement}

\begin{tabular}{crrr} 
Disagree & \multicolumn{2}{r}{ Neutral } & \multicolumn{2}{c}{ Agree } \\
\hline n $\%$ & n & $\%$ & n $\%$
\end{tabular}

A1.1 Development of sustainable and green neighbourhood is important for improving the quality of life.

$50 \quad 100.0$

A1.2 City planners and developers need to contribute towards creating quality property development.

City planners, developers and assessors should define

A1.3 the economic value of a landscape architecture development in property.

Landscape architecture for physical entities, economic

A1.4 entities and social entities and institutions is a need for quality property.

Individual / community should be aware of the fact that

A1.5 increased quality environment is essential and it has economic value.

It is a continuing need for urban planners, developers,

A1.6 owners to develop the economic landscape architecture for quality property development.

A1.7 Each residential property development schemes/ mix commercial needs a quality landscape architecture.

A1.8 Purchaser/ owner shall be entitled to enjoy the development of the landscape architecture quality.

Provision of landscape architecture development

A1.9 spending by $25 \%$ of the development is to be deemed necessary.

A1.10 Expenditure on landscape architecture which is $10 \%$ of the development expenditure is to be deemed necessary.

\section{0}

$5 \quad 10.0$
24.0

$48 \quad 96.0$

24

$48 \quad 96.0$

$50 \quad 100.0$

24.0

$48 \quad 96.0$

$50 \quad 100.0$

$2 \quad 4.0 \quad 48 \quad 96.0$

Local authorities with relevant agencies should set

A1.11 planning/ landscape architecture development to occupy at least $30 \%$ of the overall property development.

Table 3: The relationship between gender and variables

\begin{tabular}{|c|c|c|c|c|c|}
\hline Variable & Gender & Min & $\mathrm{sp}$ & $\mathrm{t}$ & sig \\
\hline \multirow{2}{*}{ Function Urban Park } & male & 2.92 & 0.22 & \multirow{2}{*}{-.384} & \multirow{2}{*}{.703} \\
\hline & female & 2.94 & 0.14 & & \\
\hline \multirow{2}{*}{ Perception } & male & 2.73 & 0.30 & \multirow{2}{*}{-.858} & \multirow{2}{*}{.396} \\
\hline & female & 2.81 & 0.29 & & \\
\hline \multirow{2}{*}{ Satisfaction } & male & 2.65 & 0.39 & \multirow{2}{*}{1.429} & \multirow{2}{*}{.161} \\
\hline & female & 2.46 & 0.50 & & \\
\hline \multirow{2}{*}{ Health } & male & 2.97 & 0.09 & \multirow{2}{*}{-.210} & \multirow{2}{*}{.835} \\
\hline & female & 2.97 & 0.11 & & \\
\hline \multirow{2}{*}{ Ecology } & male & 2.73 & 0.28 & \multirow{2}{*}{.564} & \multirow{2}{*}{.575} \\
\hline & female & 2.68 & 0.30 & & \\
\hline \multirow{2}{*}{ Planning } & male & 2.87 & 0.23 & \multirow{2}{*}{2.037} & \multirow{2}{*}{.047} \\
\hline & female & 2.72 & 0.27 & & \\
\hline
\end{tabular}




\subsection{RELATIONSHIP OF LANDSCAPE ARCHITECTURE AND PROPERTY}

The results show that $100 \%$ of respondents agreed that the development of sustainable and green neighborhood is essential for improving quality of life. In addition, $100 \%$ of respondents agreed that the city planning, development and evaluation should play a role in creating quality property development. About $96 \%$ of respondents felt that the town planners, developers and valuers should define the economic value of a development of landscape architecture in the property. In addition, about $96 \%$ of respondents agreed that the landscape architecture for physical entities, economic entities and social entities and institutions is needed for quality property. The respondents said that the public should realize that the enhancement of quality is important and it has contributed to significant economic value. Approximately 100\% of respondents agreed that the person/ people should realize enhancement of quality is important and it has significant economic value. The majority of respondents (96\%) agreed that it is a continuing need for urban planners, developers, owners to develop the economic landscape architecture for quality property development. $100 \%$ of respondents were also in unison to say that every residential property development schemes/ commercial mixed require quality landscape architecture.

A significant number of respondents also agreed that the purchaser/ owner is entitled to enjoy quality landscape architecture development. More than half of the respondents agreed that the provision of landscape architecture development spending which is $25 \%$ of that for the entire development is necessary. The study also demonstrates that over three quarter of respondents agreed that local authorities with relevant agencies should set planning/ landscape architecture development to occupy at least $30 \%$ of the overall development of the property.

\subsection{INFERENTIAL ANALYSIS}

Several independent $t$ test results have shown that there is no significant relationship between gender and respondents' feedback on the functioning of the municipal garden $(\mathrm{df}=42, \mathrm{t}=-0384, \mathrm{p}>0.05)$. The same result is for gender where it does not influence the perception of the respondents $(\mathrm{df}=$ $42, t=-0858, p>0.05)$. There is also no significant correlation between gender and satisfaction $(\mathrm{df}=$ $42, t=1: 43, p>0.05)$ and between gender and health $(\mathrm{df}=48, \mathrm{t}=-0210, \mathrm{p}<.005)$. Results of the analysis have shown that there is a significant relationship between gender and development $(\mathrm{df}=$ $48, \mathrm{t}=2038, \mathrm{p}<0.05)$. Male respondents $(2.87 \pm$ $0.23)$ have demonstrated more positive feedback than the opposite gender $(2.87 \pm 0.23)$.

\subsection{REGRESSION ANALYSIS}

The results of the multiple regression analysis show that satisfaction and urban ecology influence the importance of the development of public spaces (DF $6.18=4920, p<0.05$ ). The use of city parks, perception, health and planning and site design does not have any significant relationship with the level of interest of the public space. This model explains $62.1 \%$ variance in the dependent variable changes. With reference to the beta, each unit changes in terms of satisfaction, and subsequently there is a change of -0.46 units in the dependent variable. Along with the ecology of the city, each unit changes the level of interest of the public space, and further causing a change of 1.07 units in the dependent variable.

Table 4: Regression Analysis

\begin{tabular}{llllll}
\hline \multirow{2}{*}{ Model } & \multicolumn{2}{l}{ Unstandardized Coefficients } & \multicolumn{2}{l}{$\begin{array}{l}\text { Standardized } \\
\text { Coefficients }\end{array}$} & \multirow{2}{*}{ Sig. } \\
\cline { 2 - 4 } & $\mathrm{B}$ & Std. Error & Beta & 3.011 & .008 \\
\hline (Constant) & 1.741 & .578 & & .474 & .641 \\
City Park Usage & .090 & .190 & .107 & -1.004 & .329 \\
Perception & -.220 & .219 & -.261 & -2.447 & .025 \\
Satisfaction & -.460 & .188 & -.663 & -.822 & .422 \\
Health & -.227 & .276 & -.259 & 3.027 & .007 \\
Urban Ecology & 1.071 & .354 & 1.166 & 1.319 & .204 \\
Planning and Site Design & .358 & .272 & .414 &
\end{tabular}

$\mathrm{DF}_{6,18}=4.920, \mathrm{R}^{2}=0.621 \quad$ Dependent Variable $=$ Significance level of public space development 


\section{DISCUSSION}

The final segment presents a discussion on the findings and conclusions of the study. Therefore, the first part of this chapter gives the results and it also draws conclusions and implications based on several theories and research questions based on an assessment of the landscape architecture and real estate. The second part emphasizes the relationship discovery of goals and objectives, followed by the discovery of the importance and contribution to the theory and the body of knowledge in the third section. The fourth section describes the limitations of the study and recommendations for the direction for future research.

\subsection{SUMMARY OF THE INVENTION}

This study was conducted to determine the importance of landscape architecture in real estate development. Studies conducted to determine differences in the landscape architecture in the real estate development located in Bandar Baru Bangi. In addition, due to the economic theory, the model that allows for the identification of landscape architecture contributing to the development of the property has been developed.

In discussing these findings, it is important to reiterate some of the limitations of the econometric approach. As stated before, the regression analysis is merely a tool to test whether or not a statistically significant association exists between variables. Next, the regression analysis cannot prove that the cause and effect relationship exists, but it can only test the strength and direction of the quantitative relationship.

\subsection{THE RELATIONSHIP OF THE INVENTION AGAINST THE GOALS AND OBJECTIVES}

The relationship with the goals and objectives of the present invention is determined based on the objectives of the study and the analysis of the findings.

The objectives of the study:

1. To identify the role of landscape architecture in real estate development.

2. To determine the factors that are significant in the development of landscape architecture.

3. To define the level of importance of landscape architecture in real estate development.

4. To study the relationship between landscape architecture and property development.

\subsection{CONCLUSION}

The findings translate customer needs and the reality into a confirmed role of the development of landscape architecture as an entity property. Urban parks, local parks, urban forests, green lawns, game and recreational sites, recreational lakes and so on constitute an important amenity and consider the need for users or local residents. Nevertheless, the public perception may not include all scientific explanations believed to be contained in the components of this landscape architecture

\subsection{LIMITATIONS OF STUDY}

After the above discussion and explanation, there are still some restrictions or limitations to this study. First of all, there is a need to consider the source of the data in future studies. Overall, it is important that researchers need to take a more systematic approach in explaining the properties of physical entities, economic and social entities, and institutions in landscape architecture and explain its contribution to the development of the property. It is able to provide more dimensional views and performance improvements for landscape architecture in communities or organizations in Malaysia.

Second of all, these issues need to include the operation of landscape architecture in the global practice. Convergence and the emphasis on the local context alone may prevent or delay the benefits and productivity of landscape architecture in the existing needs of the property. The perception of different environments and practices relative to each dimension by any organization can give a bigger picture as to how the landscape architecture can be developed more effectively in improving the performance of the strategic development of the property.

Thirdly, this study aims to enlighten and encourage researchers and practitioners on the role of integrating strategic issues in landscape architecture towards improving the performance of properties. This study anticipates the reaction rates that are quite high but the size of the sample (50) is relatively small. Therefore, it requires a careful analysis in interpreting or formulating decisions. A larger sample would lead to greater accuracy.

\subsection{RECOMMENDATIONS FOR FUTURE RESEARCH}

The landscape architecture design quality is relevant for future research, as it is responsible in improving the value of the property as it is a component of the development. It is as important as 
the provision of basic amenities such as planning roads, electricity, water supply and so on. Planning a city equipped with a certain degree of awareness is necessary to ensure an improved quality of life in the society.

Planning and development of landscape architecture in each real estate development should focus on the following areas:

a) The planning of landscape architecture development should be implemented at an early stage and with the approval of subdivision.

b) The department or agency that has a role in the planning and construction of a building shall adopt a policy of conservation of green areas and improve the existing guidelines wisely.

c) Green-integrated network in cities should be established in every city and become the ultimate system policy towards greening urban settlements. Developing gardens for each real estate development should be the key component in the development and distribution of land use.

\section{REFERENCES}

Mar Iman, A. H. (2005). Pembangunan alam bina dan harta tanah. Johor: UTM Publication.

Cronbach, L.J. (1951). Coefficient alpha and the international structure of testspsychometrica. Journal Psychometrica, 16(3), 297-334.

Institute of Landscape Architects Malaysia (1995). Annual Report. Kuala Lumpur: ILAM Publication.

Ministry of Housing and Local Government (2010). Pembangunan mampan dan kejiranan hijau. Laporan Tahunan - Jabatan Perancangan Bandar dan Desa (Semenanjung Malaysia). Kuala Lumpur: JPBD Publication.

Usilappan, M. (2006). Real estate in Malaysia: Challenges, insights and issues. Kuala Lumpur: University of Malaya Press.

Laurie, M. (1975). An introduction to landscape architecture. London: Elsevier Publishing Company, Incorporated.

Nunally, D. (1978). Multi level statistical model. New York: Mac Millian Press Ltd.

Osman, S. (2006). Asas pengurusan harta tanah. Sintok: Universiti Utara Malaysia Publisher. 